\title{
Kinetics of adherence of mucoid and non-mucoid Pseudomonas aeruginosa to plastic catheters
}

\author{
L. MARTINEZ-MARTINEZ, A. PASCUAL and E. J. PEREA \\ Department of Microbiology, School of Medicine, University of Sevilla, APDO. 914, 41080 Sevilla, Spain
}

\begin{abstract}
Summary. The adherence of six non-mucoid and three mucoid strains of Pseudomonas aeruginosa to polyvinyl chloride (PVC), polyurethane (PU) and siliconised latex (SL) was evaluated by a radiometric method and scanning electronmicroscopy. Initially greater numbers of mucoid than non-mucoid strains adhered to all three materials. Hydrophobic non-mucoid strains adhered more efficiently than hydrophilic strains. Numbers of adherent non-mucoid $P$. aeruginosa cells increased with time, reaching a peak, which was different for each strain, at 1-4 h for PU, 4 h-2 days for SL and 2-3 days for PVC; thereafter a gradual decrease was observed, maximal and final values of adherence being higher with PVC and SL than with PU. Adherence of mucoid strains increased with time in 3-5 days, until a steady state was reached. We conclude that although non-mucoid strains of $P$. aeruginosa initially colonise plastic surfaces better than mucoid strains, mucoid strains also persist on these surfaces.
\end{abstract}

\section{Introduction}

Pseudomonas aeruginosa is a common cause of infection in immunocompromised patients and those with cystic fibrosis. ${ }^{1,2}$ It is an important cause of hospital acquired infection such as urinary tract infection and pneumonia. ${ }^{3}$

$P$. aeruginosa can adhere to solid surfaces ${ }^{4}$ and colonisation of inanimate surfaces by micro-organisms depends on properties of the micro-organism and the environment. ${ }^{5}$ Initial adherence is considered to depend mainly on surface properties of bacteria, such as surface hydrophobicity and net surface charge. Synthesis of exopolysaccharide materials (slime) appears to be the most important factor for irreversible adherence of bacteria. ${ }^{4}$

Previous studies on bacterial adherence to catheters and other medical devices have been done with Staphylococcus spp. (mainly $S$. epidermidis), ${ }^{6,7}$ enterobacteria $^{8,9}$ and $P$. aeruginosa. ${ }^{10,11,12}$ Most of these studies used electronmicroscopy, but no kinetic models have been established.

In this paper we describe a kinetic model of adherence for mucoid and non-mucoid strains of $P$. aeruginosa to three different materials-polyvinyl chloride, polyurethane and siliconised latex.

\section{Materials and methods}

\section{Strains}

Six non-mucoid (strains 1-6) and three mucoid

Received 2 Jan. 1990; revised version accepted 1 June 1990. strains (7-9) of $P$. aeruginosa isolated from clinical sources at the Hospital Universitario de Sevilla, Spain, were used. Strains 1 and 5 were cultured from wounds, strain 2 from blood, strain 3 from pharyngeal exudate, strain 4 from bronchial aspirate, strain 6 from urine from a catheterised patient and strains 7-9 from sputum of patients with cystic fibrosis.

A non-mucoid variant of strain 9 was obtained by culturing the original strain in Tryptic Soy Broth (TSB) (Difco) at $37^{\circ} \mathrm{C}$ for $18 \mathrm{~h}$ (i.e., to the stationary phase), and subculturing on Tryptic Soy Agar (Difco) at $37^{\circ} \mathrm{C}$ for $48 \mathrm{~h}$ to isolate non-mucoid variants.

Strains were identified according to standard methods and by the API 20NE System (API System SA, France).

Heavy suspensions of each strain in TSB with glycerol $10 \%$ were stored in small volumes at $-70^{\circ} \mathrm{C}$.

\section{Biomaterials}

Catheters made of three different materials were assessed: polyvinyl chloride (PVC) (neonatal umbilical catheter, Argyle ${ }^{\circledR} 3 \cdot 5$, Sherwood Medical Industries Ltd, Belgium); siliconised latex (SL) (pediatric foley catheter, INMED ${ }^{\circledR}$, Malaysia); and polyurethane (PU) (peripheral venous catheter, Cavafix Certo $^{\circledR}$; B. Braun Melsungen AG, FRG, kindly supplied by Palex, Spain). The catheters were cut into $1-\mathrm{cm}$ lengths under sterile conditions.

\section{Surface hydrophobicity}

The method of Rosenberg et al. ${ }^{13}$ was used to determine surface hydrophobicity: $3 \mathrm{ml}$ of phosphatebuffered saline (PBS), pH 7·2-7.4, containing $10^{9} \mathrm{cfu} /$ 
$\mathrm{ml}$ (measured by spectrophotometry-initial optical density, $O D_{1}$ ) was vortex-mixed for $1 \mathrm{~min}$ with $0.35 \mathrm{ml}$ of $p$-xylene (Merck, FRG), left for 30 min to allow phase separation and the OD of the aqueous phase was again measured (final optical density, $\mathrm{OD}_{\mathrm{F}}$ ). Surface hydrophobicity was expressed as a percentage according to the formula:

Surface hydrophobicity $=\left[1-\left(\mathrm{OD}_{\mathrm{F}} / \mathrm{OD}_{\mathrm{I}}\right)\right] \times 100$.

\section{Adherence to catheters}

Bacteria were grown in $5 \mathrm{ml}$ of TSB containing (2${ }^{3} \mathrm{H}$ )-adenine (24 Ci/mmol) (Amersham) $10 \mu \mathrm{l}$ for $18 \mathrm{~h}$ at $37^{\circ} \mathrm{C}$. After centrifugation $\left(5000 \mathrm{~g}, 15 \mathrm{~min}, 4^{\circ} \mathrm{C}\right)$ bacteria were washed three times with $10 \mathrm{ml}$ of cold PBS. A PBS suspension of each strain containing radiolabelled bacteria $\left(10^{8} \mathrm{cfu} / \mathrm{ml}\right)$ was prepared; $100 \mu$-samples of each suspension and $2.5 \mathrm{ml}$ of scintillation cocktail were vortex-mixed for $1 \mathrm{~min}$ in polypropylene vials (Biovials ${ }^{\circledR}$, Beckman, USA) and radioactivity was counted in a liquid scintillation system (Wallac 1210 Ultrobeta, LKB, Sweden). Three vials were counted for each suspension, and labelling efficiency was calculated by dividing the initial counts by the mean $(\times 10)$ of the cpm values obtained.

Two pieces of catheter were used for each measurement at 5,15 and $30 \mathrm{~min}, 1,4$ and $8 \mathrm{~h}$, and 1-7 days. Catheter pieces were initially wetted by immersing for $1 \mathrm{~h}$ in $10 \mathrm{ml}$ of PBS at $37^{\circ} \mathrm{C}$ and then transferred to $10 \mathrm{ml}$ of labelled bacterial suspension in $25 \mathrm{ml}$ screwcapped sterile glass bottles at $37^{\circ} \mathrm{C}$. At each specified time two pieces of catheter were carefully removed and washed five times with cold PBS to remove nonadherent bacteria. The final washing was checked to ensure that it was free from radioactivity. Each piece was then placed in a polypropylene vial, vortex-mixed for $1 \mathrm{~min}$ with $2.5 \mathrm{ml}$ of scintillation cocktail and counted as before. Values, in cpm, and numbers of adherent bacteria were calculated for each segment of catheter. The total surface area of each segment was calculated and final results were expressed as adherent $\mathrm{cfu} / \mathrm{cm}^{2}$ of material.

Table I. Surface hydrophobicity of P. aeruginosa strains.

\begin{tabular}{cc}
\hline Strain no. & $\begin{array}{c}\text { Surface hydrophobicity-mean (SD) } \\
\text { of three determinations }\end{array}$ \\
\hline 1 & $17 \cdot 9(2 \cdot 4)$ \\
2 & $42 \cdot 1(0 \cdot 4)$ \\
3 & $15 \cdot 0(0 \cdot 6)$ \\
4 & $15 \cdot 0(3 \cdot 5)$ \\
5 & $18 \cdot 8(2 \cdot 0)$ \\
6 & $44 \cdot 6(6 \cdot 4)$ \\
$7^{*}$ & $23 \cdot 0(12 \cdot 0)$ \\
$8^{*}$ & $20 \cdot 5(1 \cdot 8)$ \\
$9^{*}$ & $22 \cdot 4(5 \cdot 1)$ \\
\hline
\end{tabular}

*Mucoid strains.

\section{Scanning electron microscopy (SEM)}

Adherence of strain 2 to all three materials was studied at 5,15 and $30 \mathrm{~min}$ and $1,4,8$ and $24 \mathrm{~h}$ by SEM. After removing the pieces of catheter from the bottles they were fixed in paraformaldehyde $1 \%$ glutaraldehyde $10 \%$ for 3-4h. After washing with PBS for $5 \mathrm{~min}$, samples were treated for 20 min with osmium tetroxide $1 \%$ and dehydrated in increasing concentrations of ethanol $(70 \%, 90 \%, 96 \%$ for $5 \mathrm{~min}$ each and $100 \%$ for $3 \mathrm{~h}$ ). Pieces of catheter were dried by the $\mathrm{CO}_{2}$ critical point technique, fixed on aluminium stubs, covered with a $300 \mathrm{~A}$ gold film and observed by scanning electronmicroscopy (ISI-SX-25, Japan).

\section{Statistical analysis}

All the experiments were done in duplicate (except for SEM) and the mean value was calculated; where appropriate comparisons were made by Student's $t$ test; values of $p<0.05$ were regarded as significant.

\section{Results}

\section{Surface hydrophobicity}

Values obtained with the test strains ranged from 15.0 SD $0.6 \%$ (strain 3) to 44.6 SD $6.4 \%$ (strain 6). Two of the strains ( 2 and 6 ) were relatively hydrophobic (surface hydrophobicity $>40 \%$ ), the rest were relatively hydrophilic (surface hydrophobicity $<20 \%$ ). Tests with all three mucoid strains gave intermediate values: 20.5 SD $1.8 \%$ to 23.0 SD $12.0 \%$ (table).

\section{Adherence of non-mucoid and mucoid strains to catheter materials}

The kinetics of adherence are shown in fig. 1.

Adherence to $P V C$. The number of adherent bacteria of mucoid strains increased with time, reaching maximal adherence (MaxAdh), at 2 days (strain 7: $0.36 \times 10^{6} \mathrm{cfu} / \mathrm{ml}$ ), 6 days (strain $8: 1.8 \times 10^{6} \mathrm{cfu} / \mathrm{ml}$ ) and 7 days (strain $9: 1.2 \times 10^{6} \mathrm{cfu} / \mathrm{ml}$ ).

Generally, initial adherence $(5 \mathrm{~min})$ to PVC was higher (10-30-fold) for non-mucoid (0.49 SD 0.14x $\left.10^{6} \mathrm{cfu} / \mathrm{cm}^{2}\right)$ than for mucoid strains $(0.031$ SD $0.027 \times$ $\left.10^{6} \mathrm{cfu} / \mathrm{cm}^{2}\right)$. There were significant differences in adherence between more hydrophobic ( 2 and 6$)$ and more hydrophilic non-mucoid strains $(1,3,4$ and 5) after $60 \mathrm{~min}$ of interaction: $3.00 \mathrm{SD} 0.80 \times 10^{6} \mathrm{cfu} /$ $\mathrm{cm}^{2}$ and 1.25 SD $0.41 \times 10^{6} \mathrm{cfu} / \mathrm{cm}^{2}(\mathrm{p}<0.01)$. After $4 \mathrm{~h}$, adherence was independent of surface hydrophobicity.

The number of adherent non-mucoid bacteria increased over 3 days, reaching MaxAdh between $2.4 \times 10^{6}$ (strain 4) and $19 \times 10^{6} \mathrm{cfu} / \mathrm{cm}^{2}$ (strain 3). Strain 6 was the only non-mucoid strain that reached MaxAdh in 60 min.

Thereafter the number of adherent bacteria de- 

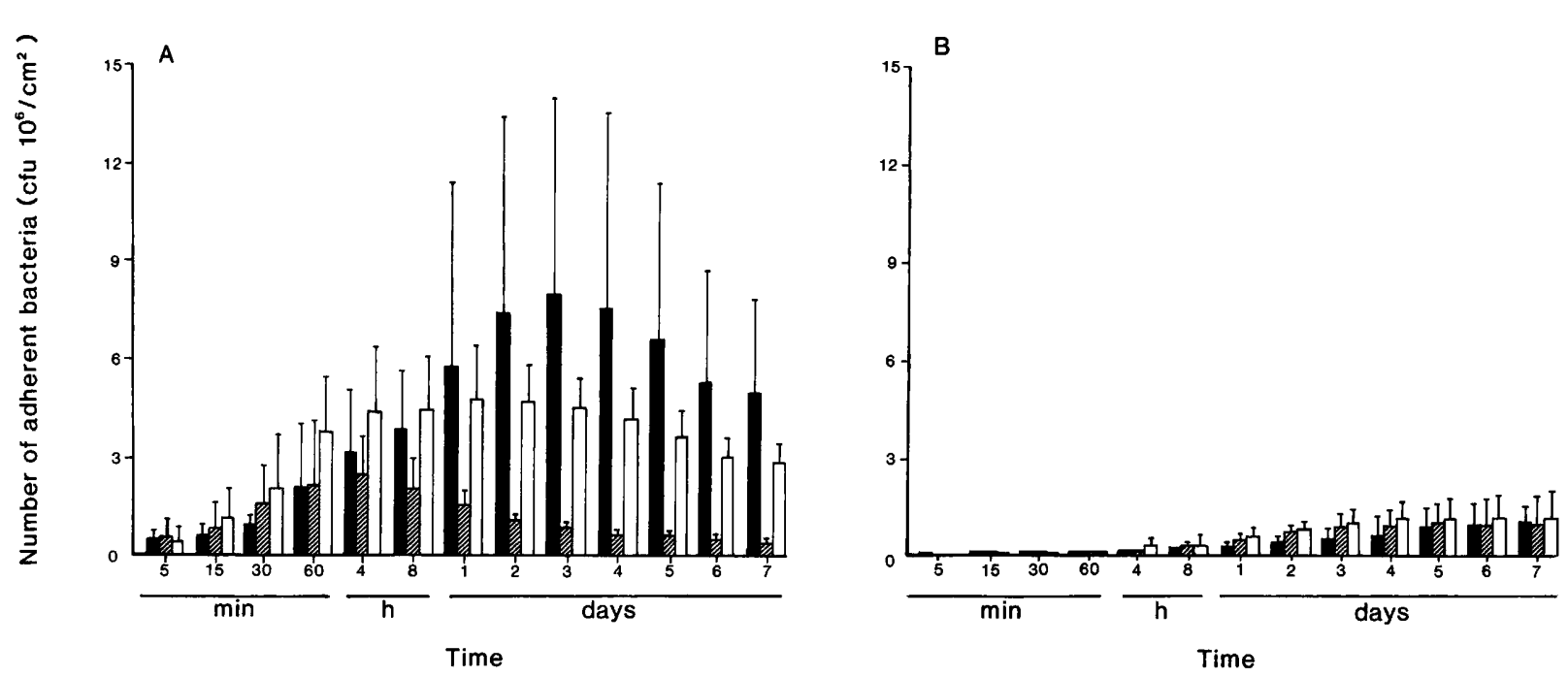

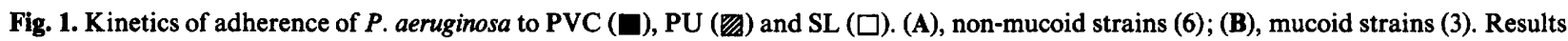
are mean values of three experiments, bar $=S D$.

creased slowly; at 7 days the numbers of adherent bacteria ranged from $0.9 \times 10^{6}$ (strain 6) to $8.7 \times$ $10^{6} \mathrm{cfu} / \mathrm{cm}^{2}$ (strain 2). MaxAdh values were significantly higher in non-mucoid $\left(8.8 \mathrm{SD} 6.7 \times 10^{6} \mathrm{cfu} /\right.$ $\left.\mathrm{cm}^{2}\right)$ than in mucoid $\left(1 \cdot 1 \mathrm{SD} 0.7 \times 10^{6} \mathrm{cfu} / \mathrm{cm}^{2}\right)$ strains $(\mathrm{p}<0.05)$.

Adherence to $P U$. Mucoid strains were initially less adherent $\left(0.016 \mathrm{SD} 0.010 \times 10^{6} \mathrm{cfu} / \mathrm{cm}^{2}\right)$ than nonmucoid ones $\left(0.49 \mathrm{SD} 0.35 \times 10^{6} \mathrm{cfu} / \mathrm{cm}^{2}\right)(\mathrm{p}<0.01)$. MaxAdh was also lower with mucoid (1.1 SD $0.5 \times$ $\left.10^{6} \mathrm{cfu} / \mathrm{cm}^{2}\right)$ than with non-mucoid strains (3.3 SD $\left.1.6 \times 10^{6} \mathrm{cfu} / \mathrm{cm}^{2}\right)(\mathrm{p}<0.01)$, but final adherence was higher in mucoid strains $\left(1.0 \mathrm{SD} 0.6 \times 10^{6} \mathrm{cfu} / \mathrm{cm}^{2}\right)$ than in non-mucoid strains $\left(0.35 \mathrm{SD} 0.1 \times 10^{6} \mathrm{cfu} /\right.$ $\mathrm{cm}^{2}$ ).

Differences between hydrophilic and hydrophobic non-mucoid strains were significant only in the first

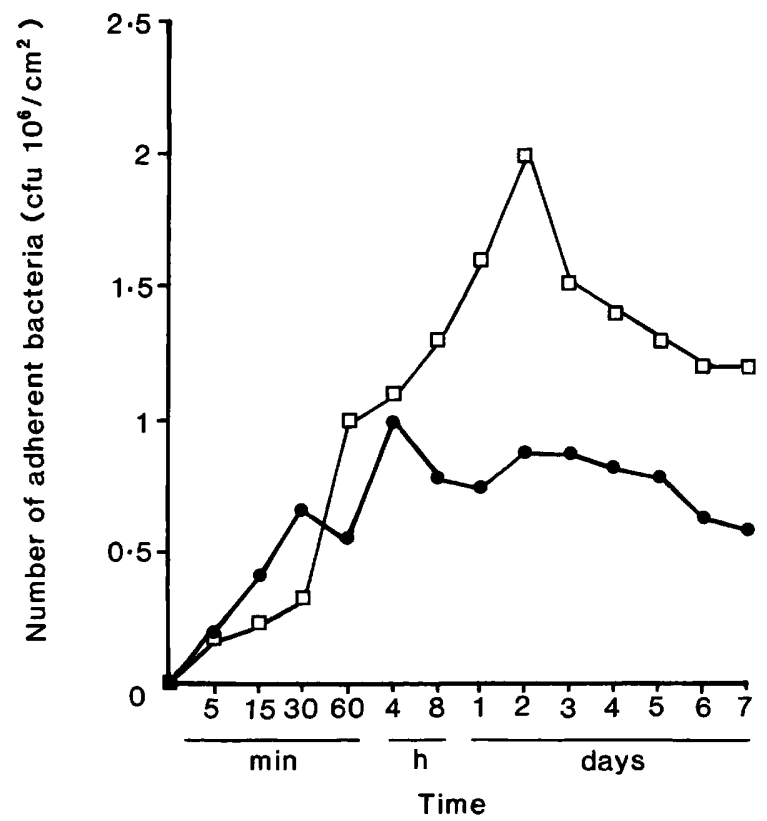

$5 \mathrm{~min}: 0.28 \mathrm{SD} 0.16 \times 10^{6}$ and $0.90 \mathrm{SD} 0.14 \times 10^{6} \mathrm{cfu} /$ $\mathrm{cm}^{2}$ respectively $(\mathrm{p}<0.01)$. MaxAdh was reached in only $4 \mathrm{~h}$ with non-mucoid strains and was $2 \cdot 7$-fold lower than that observed with PVC. Adherence decreased slowly, reaching a minimum at 7 days.

Adherence to $S L$. Mucoid strains adhered less efficiently $\left(0.017 \mathrm{SD} 0.012 \times 10^{6} \mathrm{cfu} / \mathrm{cm}^{2}\right)$ than nonmucoid strains $\left(0.41 \mathrm{SD} 0.28 \times 10^{6} \mathrm{cfu} / \mathrm{cm}^{2}\right)(\mathrm{p}<0.01)$ and final numbers of adherent bacteria (1.2 SD $0.8 \times$ $10^{6}$ and $2.9 \mathrm{SD} 0.6 \times 10^{6} \mathrm{cfu} / \mathrm{cm}^{2}$ ) were also significantly lower with mucoid than non-mucoid strains.

There were significant differences at $5 \mathrm{~min}$ between hydrophilic and hydrophobic non-mucoid strains (0.29 SD $0.14 \times 10^{6}$ and 0.72 SD $\left.0.18 \times 10^{6} \mathrm{cfu} / \mathrm{cm}^{2}\right)(\mathrm{p}<$ 0.05 ) and MaxAdh was reached in 1-4 h with hydrophobic strains and 1-2 days with hydrophilic strains.

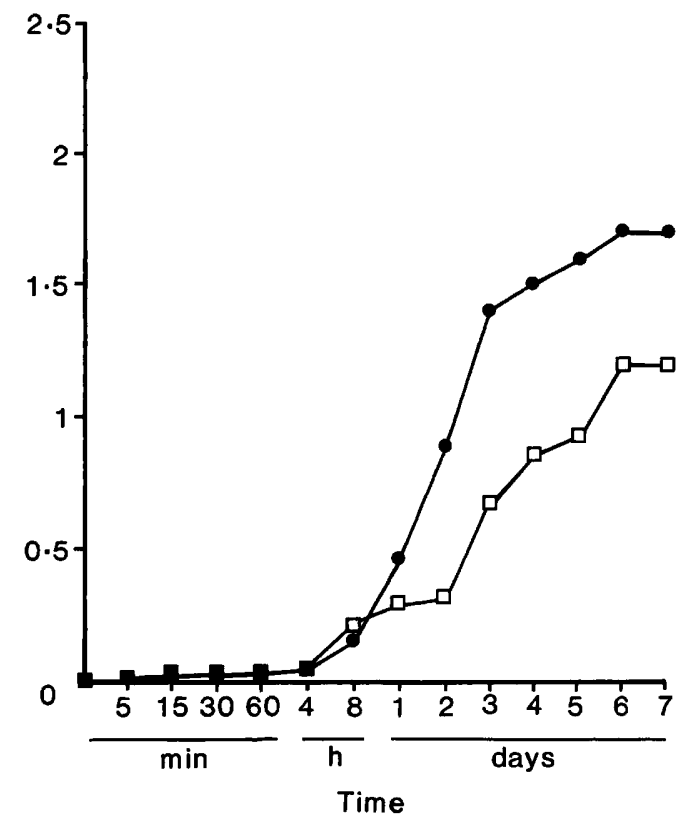

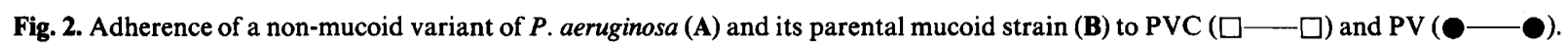



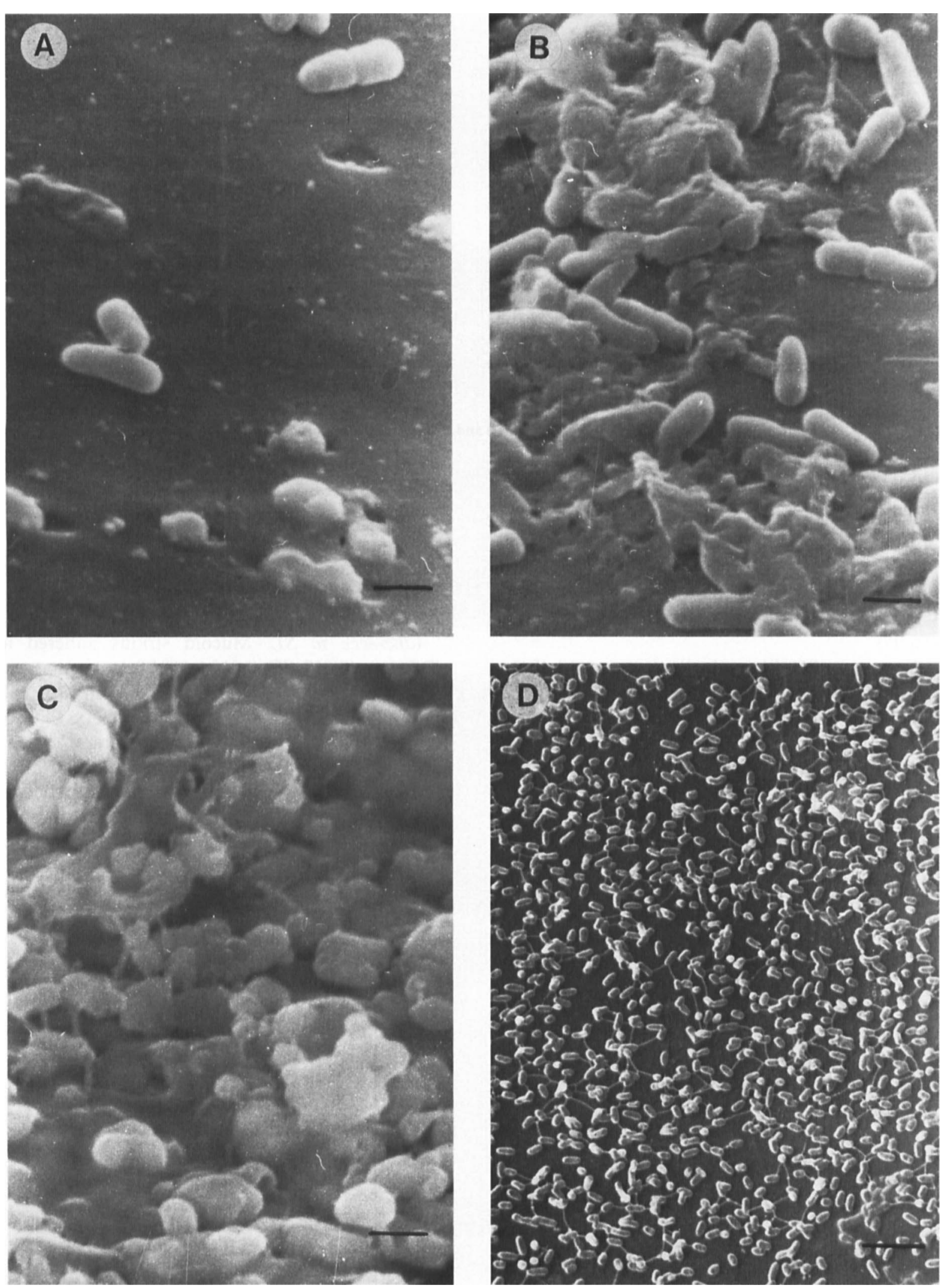

Fig. 3. Adherence of a non-mucoid strain of $P$. aeruginosa to PVC: A, $5 \mathrm{~min} ; \mathrm{B}, 60 \mathrm{~min} ; \mathrm{C}, 24 \mathrm{~h}(\times 10000$; bar $=1 \mu \mathrm{m}) \mathrm{D}$, Adherence to PU at $24 \mathrm{~h}(\times 2500 ; \mathrm{bar}=4 \mu \mathrm{m})$.

\section{Adherence to PVC and PU of a non-mucoid variant from a mucoid strain}

A non-mucoid variant of strain 9 had a similar kinetic model with PVC and PU to that observed in initially non-mucoid strains $1-6$. At $5 \mathrm{~min}$, adherence to PVC $\left(0.17 \times 10^{6} \mathrm{cfu} / \mathrm{cm}^{2}\right)$ and PU $\left(0.19 \times 10^{6} \mathrm{cfu} /\right.$ $\mathrm{cm}^{2}$ ) was 17- and 19-fold higher than with the original mucoid strain $\left(0.01\right.$ and $\left.0.098 \times 10^{6} \mathrm{cfu} / \mathrm{cm}^{2}\right)$.

MaxAdh for this non-mucoid variant was reached 
at 2 days (PVC) and $4 \mathrm{~h}$ (PU), in contrast to 7 days with the mucoid parent (fig. 2).

\section{$S E M$}

Fig. 3 shows the adherence of strain 2 to $P V C$ and PU with time. At 5 min (Fig. 3A) a few microorganisms appear on PVC, some of them occupying irregularities on the surface; after $1 \mathrm{~h}$, the number of adherent bacteria increased, and an amorphous material was evident around the micro-organisms (fig. $3 \mathrm{~B})$; at $24 \mathrm{~h}$ slime could be seen covering a multilayer bacterial biofilm (fig. 3C). Similar pictures were obtained with SL catheters (not shown). Adherence to PU was similar at 5 and $60 \mathrm{~min}$ but at $24 \mathrm{~h}$ the bacteria formed a single layer of cells with no sign of slime production (fig. 3D).

\section{Discussion}

Colonisation of medical devices by $P$. aeruginosa is likely to depend on the ability to adhere to solid surfaces $^{4,10,14}$ which then allows micro-organisms to form biofilms in which they are protected from harmful environmental factors. ${ }^{4}$

Most studies of microbial factors involved in adherence to inert surfaces have focused on physical forces such as surface hydrophobicity. Our strains were neither strictly hydrophobic nor strictly hydrophilic. Our results agree with those of Speert et al. ${ }^{15}$ who obtained values ranging from $15 \%$ to $65 \%$ with a polyethyleneglycol-dextran system. Previous reports have shown that hydrophobic micro-organisms adhere more efficiently to hydrophobic substrata than hydrophilic ones. ${ }^{4,7,16-18}$ Our results confirmed that hydrophobicity of non-mucoid strains of $P$. aeruginosa was important during the first $5 \mathrm{~min}$ of interaction with catheters. Surface hydrophobicity did not appear to be important thereafter. Mucoid strains had intermediate surface hydrophobicity values, but initial adher- ence to all three types of catheter was lower than for non-mucoid strains with similar surface hydrophobicity.

Different patterns of adherence to plastics were observed with non-mucoid and mucoid strains. With non-mucoid strains, adherence increased throughout the time reaching a peak (MaxAdh) quantitatively different for different strains. After MaxAdh was reached, the adherent population decreased slowly during the study period (7 days). Adherence of mucoid strains slowly increased until a steady state was reached (Fig. 1).

The difference in behaviour of mucoid and nonmucoid strains was confirmed by comparing the adherence of a mucoid strain and its non-mucoid variant to $P V C$ and $P U$.

The production of slime has been shown to be important for colonisation of both medical devices ${ }^{2,19}$ and cell surfaces. ${ }^{20,21}$ Slime can also protect $P$. aeruginosa from antimicrobial drugs ${ }^{22,23}$ and host defence mechanisms. ${ }^{24,25}$ The mechanisms involved in mucoid-non-mucoid reversion are only partially understood but the recent finding of polyuronicdepolymerase activity in $P$. aeruginos ${ }^{26}$ and the recognition of slime production by "non-mucoid" strains $^{27}$ are significant. Our electronmicrographs confirmed that synthesis of a slime-like material was involved in adherence of non-mucoid strains. This slime-like material is known to consist of three chromatographic fractions, one of them being uronic acid, as in the slime produced by mucoid strains. ${ }^{27,28}$

Adherence values were also influenced by the nature of the material especially with non-mucoid strains. These differences may justify in-vitro studies of microorganism-material interactions when evaluating the application of new materials for clinical use.

This work was supported by Comisión Asesora de Investigación Científica y Técnica. N. 85/0299. L. M-M. was a recipient of a fellowship from Plan de Formación de Personal Investigador, Ministerio de Educación y Ciencia, Spain. We thank Dr J. Ambrosiani and $\mathrm{Mr}$ C. Mosquero for their collaboration and technical assistance in the SEM studies.

\section{References}

1. Young LS. The clinical challenge of infections due to Pseudomonas aeruginosa. Rev Infect Dis 1984; 6 Suppl 3: S603S607.

2. Doggett RG. Incidence of mucoid Pseudomonas aeruginosa from clinical sources. Appl Microbiol 1969; 18: 936-937.

3. Morrison AJ, Wenzel RP. Epidemiology of infections due to Pseudomonas aeruginosa. Rev Infect Dis 1984; 6: Suppl 3: S627-S642.

4. Costerton JW. The etiology and persistence of cryptic bacterial infections: a hypothesis. Rev Infect Dis 1984; 6 Suppl 3: S608-S616.

5. Fletcher M, Loeb GI. The influence of substratum characteristics on the attachment of a marine pseudomonad to solid surfaces. Appl Environ Microbiol 1979; 37: 67-72.

6. Peters G, Locci R, Pulverer G. Adherence and growth of coagulase-negative staphylococci on surfaces of intravenous catheters. J Infect Dis $1982 ; 146: 479-482$.

7. Pascual A, Fleer A, Westardaal NA, Verhoef J. Modulation of

adherence of coagulase-negative staphylococci to Teflon catheters in vitro. Eur J Clin Microbiol 1986; 5: 518-522.

8. Sugarman B. In-vitro adherence of bacteria to prosthetic vascular grafts. Infection $1982 ; 10$ : 13-16.

9. Ashkenazi S, Mirelman D. Adherence of bacteria to pediatric intravenous catheters and needles and its relation to phlebitis in animals. Ped Res 1984; 18: 1361-1366.

10. Marrie TJ, Costerton JW. Scanning electron microscopic study of uropathogen adherence to a plastic surface. Appl Environ Microbiol 1983; 45: 1018-1024.

11. Duran JA, Refojo MF, Gipson IK, Kenyon KR. Pseudomonas attachment to new hydrogel contact lenses. Arch Ophthalmol 1987; 105: 106-109.

12. Miller MJ, Ahearn AG. Adherence of Pseudomonas aeruginosa to hydrophilic contact lenses and other substrata. J Clin Microbiol 1987; 25 : 1392-1397.

13. Rosenberg M, Gutnick D, Rosenberg E. Adherence of bacteria to hydrocarbons: a simple method for measuring cell surface hydrophobicity. FEMS Microbiol Letters 1980; 9: 29-33.

14. Costerton JW. Pseudomonas aeruginosa in nature and disease. 
In: Sabath LD (ed) Pseudomonas aeruginosa. Berne, Hans Huber. 1980: 15-24.

15. Speert DP, Loh BA, Cabral DA, Salit IE. Nonopsonic phagocytosis of nonmucoid Pseudomonas aeruginosa by human neutrophils and monocyte-derived macrophages is correlated with bacterial piliation and hydrophobicity. Infect Immun 1986; 53: 207-212.

16. Fattom A, Shilo M. Hydrophobicity as an adhesion mechanism of benthic cyanobacteria. Appl Environ Microbiol 1984; 47 : 135-143.

17. Magnusson K-E. Hydrophobic interaction-a mechanism of bacterial binding. Scand J Infect Dis 1982; Suppl 33: 3236.

18. Falkowski W, Edwards M, Schaeffer AJ. Inhibitory effect of substituted aromatic hydrocarbons on adherence of Escherichia coli to human epithelial cells. Infect Immun 1986; 52 : 863-866.

19. Marrie TJ, Costerton JW. A scanning electron microscopic study of urine droppers and urine collecting systems. Arch Intern Med 1983; 143: 1135-1141.

20. Doig PO, Smith NR, Todd T, Irvin RT. Characterization of the binding of Pseudomonas aeruginosa alginate to human epithelial cells. Infect Immun 1987, 55: 1517-1522.

21. Ramphal R, Pier GB. Role of Pseudomonas aeruginosa mucoid exopolysaccharide in the adherence to tracheal cells. Infect Immun 1985; 47: 1-4

22. Nickel JC, Ruseska I, Wright JB, Costerton JW. Tobramycin resistance of Pseudomonas aeruginosa cells growing as a biofilm on urinary catheter material. Antimicrob Agents Chemother 1985; $27: 619-624$.

23. Baltimore RS, Cross AS, Dobek AS. The inhibitory effect of sodium alginate on antibiotic activity against mucoid and non-mucoid strains of Pseudomonas aeruginosa. J Antimicrob Chemother 1987; 20 : 815-823.

24. Laharrague PF, Corberand JX, Fillola G, Gleizes BJ, Fontanilles AM, Gyrard E. In-vitro effect of the slime of Pseudomonas aeruginosa on the function of human polymorphonuclear neutrophils. Infect Immun 1984, 44: 760762.

25. Marrie TJ, Harding GKM, Ronald AR et al. Influence of mucoidy on antibody coating of Pseudomonas aeruginosa. $J$ Infect Dis 1979; 139: 357-361.

26. Dunne WM, Buckmire FLA. Partial purification and characterization of a polymannuronic acid depolymerase produced by a mucoid strain of Pseudomonas aeruginosa isolated from a patient with cystic fibrosis. Appl Environ Microbiol 1985; 50: 562-567.

27. Anastassiou ED, Mintzas AC, Kounavis C, Dimitracopoulos G. Alginate production by clinical non-mucoid Pseudomonas aeruginosa strains. J Clin Microbiol 1987; 25: 656659.

28. Evans LR, Linker A. Production and characterization of the slime polysaccharide of Pseudomonas aeruginosa.J Bacteriol 1973; 116: 915-924. 